\title{
The use of skimmed dried milk as an alternative diluent for the cooling step during the boar sêmen freezing procedure
}

\author{
Leite em pó desnatado como diluente alternativo na etapa de \\ resfriamento durante protocolo de congelação do sêmen suíno
}

\author{
Tatyane Bandeira Barros ${ }^{1}$; Daianny Barboza Guimarães ${ }^{2}$; \\ Ludymila Furtado Cantanhêde²; Aline Viana Dias²; Leonardo Peres de Souza3; \\ Jean Magloire Feugang ${ }^{4}$; Ricardo Toniolli ${ }^{5 *}$
}

\begin{abstract}
One of the critical points in the cryopreservation process is the use of a proper diluent while lowering the temperature following the resuspension and thawing processes. Here, we tested an alternative diluent for the process of freezing boar semen. We used skimmed dried milk (SDM) during the cooling and post-thawed resuspension steps. To do so, we collected semen from 15 Dalland boars using the glovedhand technique, and incubated each ejaculate sample at $30^{\circ} \mathrm{C}$. We then removed two semen aliquots from a pre-dilution. We diluted one of the aliquots in Beltsville thawing solution (BTS - control), and the remaining sample was diluted in SDM. Both aliquots were subsequently held at $30^{\circ} \mathrm{C}$ for $45 \mathrm{~min}$ $\left(1^{\text {st }}\right.$ period of stabilization). At the end of this period, we analysed vigor and motility to determine sperm metabolic activity. We then held the diluted semen at $25^{\circ} \mathrm{C}$ for $30 \mathrm{~min}\left(2^{\text {nd }}\right.$ period of stabilization $)$ and at $17^{\circ} \mathrm{C}$ for $2 \mathrm{~h}\left(3^{\text {rd }}\right.$ period stabilization). We centrifuged the semen at $800 \times g$ and $1600 \times g$ at $5^{\circ} \mathrm{C}$ for $15 \mathrm{~min}$, discarded the supernatant, and resuspended the sperm pellet in $2 \mathrm{~mL}$ of the cooling diluent at $5^{\circ} \mathrm{C}$ for $1 \mathrm{~h}$. We again diluted the samples in $2 \mathrm{~mL}$ of the freezing diluent, poured them into straws, and cooled and plunged them into liquid $\mathrm{N}_{2}$. The sêmen samples were thawed in a $39^{\circ} \mathrm{C}$ water bath, and were resuspended in their respective diluents at the same temperature. We determined the following sperm features: vigor, motility, vitality, acrosomal integrity and membrane functionality. During the first phase of temperature cooling $\left(30^{\circ} \mathrm{C}\right)$, semen diluted in SDM exhibited a higher vigor $(3.4 \pm 0.6)$ and motility (78.6 \pm 13.0 ) than those diluted BTS (vigor: $3.1 \pm 0.7$; motility: $69.4 \pm 14.3$ ). However, after the thawing procedure, the inverse was observed in that: BTS samples exhibited a higher vigor $(2.1 \pm$ $0.6)$ and motility $(35.5 \pm 21.0)$ than SDM samples (vigor: $1.7 \pm 0.9$; motility: $22.8 \pm 18.1)$. Regarding membrane functionality and acrosomal integrity, we did not find a significant difference between BTS and SDM, although SDM provided a higher percentage of living cells at the end of the freeze/thaw procedures $(72.3 \pm 16.4)$. In summary, we suggest that BTS should be considered a better option than SDM for the cooling and post-thaw resuspension steps of boar semen freezing process.
\end{abstract}

Key words: Seminal freezing, skimmed dried milk, sperm viability

\footnotetext{
${ }^{1}$ Discente de Doutorado, Programa de Pós Graduação em Ciências Veterinária, Universidade Estadual do Ceará, UECE, Fortaleza, CE, Brasil. E-mail: tatybiobandeira@yahoo.com.br

${ }^{2}$ Mestres em Ciências Veterinárias,o Programa de Pós Graduação em Ciências Veterinária, UECE, Fortaleza, CE, Brasil. E-mail: daiannybg@yahoo.com.br; lud_furtado@hotmail.com; alinedias.vet@hotmail.com

3 Prof. Adjunto, Universidade Federal do Piauí, UFPI, Parnaíba, PI, Brasil. E-mail: leoperes.professor@gmail.com

${ }^{4}$ Assistant Research Professor, Mississippi State University, MSU, Jackson, MS, USA. E-mail: jn181@msstate.edu

${ }_{5}$ Prof. Adjunto, UECE, Fortaleza, CE, Brasil. E-mail: toniolli@roadnet.com

* Author for correspondence
} 


\title{
Resumo
}

\begin{abstract}
Esse estudo objetivou testar um diluente alternativo, a base de leite em pó desnatado, durante as etapas de resfriamento e ressuspensão pós descongelação durante a congelação do sêmen suíno. Para isso o sêmen de 15 varrões da raça Dalland, foi coletado através da técnica da mão enluvada. Visando o início da curva de congelação, cada ejaculado foi incubado a $30^{\circ} \mathrm{C}$. Em seguida, foram retiradas duas alíquotas de sêmen para uma pré-diluição. Uma das alíquotas foi diluída no diluente Beltsville Thawing Solution (BTS - Controle) e a outra em leite em pó desnatado (LPD), onde permaneceram a essa temperatura por 45 minutos. O sêmen pré-diluído passou por três tempos de estabilização. Ao final do primeiro tempo $\left(30^{\circ} \mathrm{C}-45\right.$ minutos) foi realizada análise de vigor e motilidade a fim de acompanhar a atividade metabólica espermática. Em seguida o sêmen diluído passou pelas temperaturas: $25^{\circ} \mathrm{C}-30$ minutos e $17{ }^{\circ} \mathrm{C}-2$ horas. Ao final, o sêmen foi centrifugado (à $5^{\circ} \mathrm{C}-800 \mathrm{~g}-1600 \mathrm{rpm}-15$ minutos), sendo desprezado o sobrenadante, enquanto que o pellet de espermatozoides foi ressuspenso em $2 \mathrm{~mL}$ do diluente de resfriamento e mantido a $5^{\circ} \mathrm{C}$ por 1 hora. Ao final, foi realizada a $2^{\mathrm{a}}$ diluição com $2 \mathrm{~mL}$ do diluente de congelação, seguida do envaze das amostras, rampa de congelação e submergidas em N2 líquido. O sêmen foi descongelado em banho-maria $\left(39^{\circ} \mathrm{C}\right)$, ressuspendido em seus respectivos diluentes à mesma temperatura e só então analisado quanto às características de vigor, motilidade, vitalidade, integridade acrossomal e funcionalidade da membrana. Durante a primeira fase de abaixamento de temperatura $\left(30^{\circ} \mathrm{C}\right)$, observou-se que o sêmen diluído em LPD em comparação ao BTS, apresentou valores superiores de vigor $(3,4 \pm 0,6$ e $3,1 \pm 0,7$, respectivamente) e motilidade $(78,6 \pm 13,0$ e $69,4 \pm 14,3$ respectivamente). Contudo, após a descongelação verificou-se o inverso, com o BTS apresentando resultados mais altos do que o diluente alternativo LPD tanto para as análises de vigor $(2,1 \pm 0,6 \mathrm{e}$ $1,7 \pm 0,9$, respectivamente), quanto de motilidade (35,5 $\pm 21,0$ e $22,8 \pm 18,1$, respectivamente). Quanto às características de funcionabilidade de membrana e integridade acrossomal não foram observadas diferenças significativas entre os diluentes testados, entretanto o LPD apresentou maior porcentagem de células vivas ao final do processo de congelação/descongelação $(72,3 \pm 16,4)$. Diante do exposto, pôdese observar que o diluente BTS ainda é a melhor opção para ser utilizado nas etapas de resfriamento e ressuspensão pós descongelação, durante a congelação seminal em suínos.
\end{abstract}

Palavras-chave: Congelação seminal, leite em pó desnatado, viabilidade espermática

\section{Introduction}

Semen cryopreservation is an important technique for both animal husbandry and biotechnology. In the former case, it allows the interchange between the germplasm of genetically superior animals; and; it aids the conservation of endagered species through a genomic bank in the latter case. Among the advantages of this technique is the optimization for the use of proven genetically superior animals, which allows semen storage despite geographical barriers, facilitating semen shipment worldwide (BARRETO et al., 2008).

Semen cryopreservation protocols include critical steps such as cooling, freezing and thawing. To maintain spermatozoa viability in such processes, it is necessary to use proper diluents for each of above-mentioned steps. Adequately diluted semen can be frozen indefinitely, remaining potentially fertile after thawing, so it can be used in artificial inseminations (SILVA, 2007). Several authors have struggled to develop a novel diluent (e.g., milk), and these researchers focus on semen freezing processes for use in both animals and human beings (SCHMITT et al., 2003).

Regarding its chemical composition, milk has two biologically important proteins for spermatozoa preservation. The first is lactose, which acts as the energetic element; and the second is casein that, enhances kinetic activity. Additionally, milk has a buffering capacity, bactericidal action, and an adequate viscosity for the maintenance of spermatozoa in a liquid medium (CUNHA, 2002). This diluent has already been tested in protocols for freezing boar semen (TONIOLLI et al., 2001; 
ARAÚJO et al., 2013), making a potential diluent for the sêmen-cooling step.

Over the past decades, considerable research efforts have been made to establish novel protocols for the freezing of boar semen. Improved fertility outcomes of cryopreserved semen depend on many scientific fields (e.g., biochemistry and cryobiology), specific freezing methods, and the determination of ideal insemination moments. Moreover, skimmed dried milk has been shown to be an efficient spermatozoa preservative, at primarily low temperatures. Thus, during the freezing process of boar semen, our goal was to test the efficiency of skimmed dried milk during the cooling and resuspension steps.

\section{Materials and Methods}

\section{Animals and semen collection}

We used boars from the Laboratory of Swine Reproduction and Semen Technology (Laboratório de Reprodução Suína e Tecnologia do Sêmen), at the Veterinary College of the State University of Ceará (Universidade Estadual do Ceará), and from the Xerez S.A. Swine Farm (municipality of Maranguape, State of Ceará). We housed the boars individually in $10 \mathrm{~m}^{2}$ side-by-side stalls, and drove them daily to dirt-floored paddocks. The diet was composed of $2 \mathrm{~kg}$ feed/animal/day (3340Kcal E.M. and $12 \% \mathrm{~PB})$, and water ad libitum.

Once a week, we collected semen alternatively from 15 Dalland boars, ages 12 - 24 months, for a total 75 ejaculates. To obtain ejaculate samples. we used the gloved-hand technique and a dummy. All ejaculates separated from gel particles were utilized.

\section{Assessment of in natura ejaculates}

We evaluated the following ejaculate features: volume $(\mathrm{mL})$, concentration $\left(\times 10^{6}\right.$ spermatozoa/ $\mathrm{mL})$, total spermatozoa $\left(\times 10^{9}\right.$ sperm $)$, spermatozoa vigor (scores from 0 to 5 , conforme TONIOLLI,
1996), spermatozoa motility and hypoosmotic properties (values range from 0 to $100 \%$ for bo analysesth). Only ejaculates with vigor $\geq 3.5$ and motility $\geq 85 \%$ were studied.

\section{Thawing curve and semen freezing}

We removed two aliquots with $2.5 \times 10^{9}$ spermatozoa from each ejaculate and incubated them at $30^{\circ} \mathrm{C}$ for $15 \mathrm{~min}$. After this period, we prediluted one of the aliquots in Beltsville thawing solution (BTS ${ }^{\circledR}$ - control), and the remaining alíquota was prediluted in $10 \%$ skimmed dried milk (SDM) $\left(\right.$ Molico $^{\circledR}$ ) with $205 \mathrm{mM}$ glucose, $300.000 \mathrm{UI} / \mathrm{mL}$ benzylpenicillin procaine (Pencivet, Intervet ${ }^{\mathbb{R}}$ ), osmolarity $305 \mathrm{mOsmol}$, and $\mathrm{pH} 6.9$ at a ratio of 3: 1 (diluent: semen). We then initiated the thawing curve for the diluted ejaculate.

We held the pre-diluted semen in a $30^{\circ} \mathrm{C}$ water bath for $45 \mathrm{~min}$ ( $1^{\text {st }}$ period of stabilization). After this period, we held the samples at $25^{\circ} \mathrm{C}$ for $30 \mathrm{~min}$ ( $2^{\text {nd }}$ period of stabilization), and transferred them to a $17^{\circ} \mathrm{C}$ refrigerator for $2 \mathrm{~h}$ in darkness $\left(3^{\text {rd }}\right.$ period of stabilization). At the end of the second period of stabilization, we placed the semen into a $5^{\circ} \mathrm{C}$ freezer for $1 \mathrm{~h}$. After this period, we centrifuged the samples at $800 \times g$ for $15 \mathrm{~min}$ and removed and discarded the supernatant. We then resuspended the sperm pellets in $2 \mathrm{~mL}$ of the cooling diluent $(5.67 \%$ glucose and $20.00 \%$ yolk) and held them at $5^{\circ} \mathrm{C}$ for $1 \mathrm{~h}$. After the 1-h cooling period, we diluted the sperm again in $2 \mathrm{~mL}$ of the freezing diluent $(5.67 \%$ glucose, $20.00 \%$ yolk and $6.00 \%$ glycerol). We then lead the samples into $0.5-\mathrm{mL}$ straws with $250 \times 10^{6}$ spermatozoa/straw. Afterwards, we held the straws on a freezing platform and placed them in contact with nitrogen vapor for $30 \mathrm{~min}$ at $5 \mathrm{~cm}$ above the liquid nitrogen level (the temperature ranged from $-60^{\circ} \mathrm{C}$ to $-70^{\circ} \mathrm{C}$ ). To provide equilibrium to the semen, we plunged the semen into the liquid nitrogen tank at $-196^{\circ} \mathrm{C}$ for $24 \mathrm{~h}$ before thawing and sample analysis. 


\section{Fast thawing and semen resuspension}

For the thawing procedure, we warmed each straw in a $39^{\circ} \mathrm{C}$ water bath for $50 \mathrm{~s}$, and we subsequently added $2 \mathrm{~mL}$ of the respective resuspension diluent $\left(\mathrm{BTS}^{\circledR}\right.$ or LPD), which was also held at $39^{\circ} \mathrm{C}$ for 10 min. After this period, we analyzed the following features: motility, vitality, acrosomal morphology and membrane functionality.

\section{Thawed semen analyses}

Sperm vigor and percentage of motile sperm cells (motility): We poured the thawed samples into test tubes and held them in a $39^{\circ} \mathrm{C}$ water bath to assess sperm quality based on vigor (scores from 0 to 5 , where 0 means the absence of movement and 5 means a forward progressive movement) and motility $(0-100 \%)$. To do so, we placed $15-\mu \mathrm{L}$ aliquots of the resuspended semen on glass slides and examined them under light microscopy at $200 \times$ magnification.

Hypoosmotic testing: We diluted $0.5 \mathrm{~mL}$ of the semen in $7.5 \mathrm{~mL}$ of distilled water, and held the samples in a $39^{\circ} \mathrm{C}$ water bath for 15 min (solution A). After this incubation period, we added $1.0 \mathrm{~mL}$ of the mixture (solution A plus sperm cells) to 0.5 $\mathrm{mL}$ of $1 \%$ saline formaldehyde (solution $\mathrm{B}$ ). We removed $15-\mu \mathrm{L}$ aliquots of this new solution (C), placed them on glass slides, and examined them under light microscopy at $\times 400$ magnification (200 cells per sample). Straight-tailed spermatozoa were considered to have non-functional membranes, whereas those with a functional membrane encompassed the remaining types of tail folding.

Acrosomal morphology and sperm vitality: We divided the exams into two types of analyses: acrosome morphology and sperm vitality (\% of living cells). To do so, we prepared a stained semen film. The staining solution was composed of $15 \times$ $10^{-5} \mathrm{M}$ bromophenol blue and $1.6 \times 10^{-3} \mathrm{M}$ trisodium citrate in $10 \mathrm{~mL}$ of distilled water. We adjusted the osmolarity of the solution with distilled water until values between 300 and $310 \mathrm{mOsmol}$ were obtained. To prepare the semen films, we diluted the samples in the staining solution at a ratio of 1 $: 2$, placed them on glass slides, and homogenized them. After drying, we counted 200 cells per slide under light microscopy at $1000 \times$ magnification. We assigned acrosome morphology and vitality to four categories: (1) living with undamaged acrosome; (2) living with damaged acrosome; (3) dead with undamaged acrosome; (4) dead with damaged acrosome.

\section{Statistical analyses}

We analyzed our data using randomized block design, and we assessed data normality with the Kolmogorov-Smirnov test for goodness-offit. We report descriptive statistics as means and standard deviations. Moreover, we analyzed nonnormally distributed data with the Mann-Whitney $\mathrm{U}$ test. Categorical data were expressed as relative frequencies, and were also analyzed with the chisquared $\left(\chi^{2}\right)$ test. All the analyses were conducted at the 0.05 significance level using GraphPad Prism version 5.0.

\section{Results and Discussion}

\section{In natura semen}

The in natura semen from the 75 studied ejaculates (total ejaculate) exhibited normal features, including a milky white color, and a mean volume and concentration of $249.4 \mathrm{~mL}$ and 314.3 $\times 10^{6}$ spermatozoa $/ \mathrm{mL}$, respectively. Such features are in accordance with those for this swine species (CORREAA et al., 2001). The spermatozoa of all in natura ejaculates showed a mean motility and vigor of $89 \% \pm 6.0$ and $4.2 \pm 0.4$, respectively. These parameters fall within the standardized figures stipulated in our methodology (85\% and 3.5 - for percentage of motile cells and vigor, respectively). Furthermore, $57.7 \% \pm 19.9$ of the cells exhibited folded tails. 
Efeito do diluente no abaixamento de temperatura e pós descongelação

The ults indicated an interaction between the diluents and the thawing curve $(p>0.05)$. During the first thawing phase $\left(30^{\circ} \mathrm{C}\right)$, semen diluted in SDM displayed greater vigor than those diluted in commercial BTS. However, after the thawing process we observed the inverse situation in that BTS led to greater vigor than the alternative SDM diluent (Table 1). Furthermore, we found a similar pattern for sperm motility (Table 2).

Table 1. Boar sperm vigor diluted in BTS or SDM at distinct moments during the cryopreservation process: at $30^{\circ} \mathrm{C}$ and after thawing.

\begin{tabular}{ccc}
\hline Diluents & $\mathbf{3 0}^{\circ} \mathbf{C}$ & After thawing \\
\hline BTS & $3.1 \pm 0.7 \mathrm{~b}$ & $2.1 \pm 0.6 \mathrm{a}$ \\
SDM & $3.4 \pm 0.6 \mathrm{a}$ & $1.7 \pm 0.9 \mathrm{~b}$ \\
\hline
\end{tabular}

$(a, b)$ Distinct letters on the same column denote a statistically significant difference $(\mathrm{p}<0.05)$.

Table 2. Percentage of motile cells diluted in BTS or SDM at distinct moments during the cryopreservation process: at $30^{\circ} \mathrm{C}$ and after thawing.

\begin{tabular}{ccc}
\hline Diluents & $\mathbf{3 0}^{\circ} \mathbf{C}$ & After thawing \\
\hline BTS & $69.40 \pm 14.30 \mathrm{~b}$ & $35.45 \pm 21.00 \mathrm{a}$ \\
SDM & $78.60 \pm 13.00 \mathrm{a}$ & $22.80 \pm 18.10 \mathrm{~b}$ \\
\hline
\end{tabular}

(a, b) Distinct letters on the same column denote a statistically significant difference $(\mathrm{p}<0.05)$.

SDM has already been described as a seminal diluent, acting as a biologically important organic medium for spermatozoa preservation due to its buffering capacity and abundant carbohydrates, which are energetically important for these cells (MICHAJOLOV, 1950). Additionally, it shows practical and effective protection against low temperatures ( $4^{\circ} \mathrm{C}$ ) (GARCIA; GRAHAM, 1987), and it preserves sperm motility better than other diluents (KULAKSIZ et al., 2012). Our study also shows this feature, since SDM was more effective in maintaining sperm vitality during the initial cooling phase (one of the steps of seminal freezing process). The more effective results for $\mathrm{SDM}$ at $30^{\circ} \mathrm{C}$ may be accounted for by the presence of lipoproteins and lectins in the milk, which can protect sperm cells against thermal shocks when added to the semen before the cooling process (MEMON; OTT, 1981).

Although our SDM alternative was less effective than the commercial BTS after thawing, both diluents are in accordance with the recommendations for artificial insemination or in vitro fertilization (BORTOLOZZO et al., 2005). In a similar study, Bianchi et al. (2011) also showed that after thawing boar semen, sperm vitality was higher in cryopreserved samples cooled with BTS than with other diluents.

The ability of spermatozoa to fold their tails when under osmotic stress indicates that the membrane is functional (INAMASSU et al., 1999). Therefore, spermatozoa which that preserve this feature are of higher quality (NIE; WENZEL, 2001). Our studied diluents worked similarly with regard to the conservation of the sperm cell osmotic response $(\mathrm{p}>0.05)$ (Table 3$)$. However, in comparison with the in natura semen $(57.7 \% \pm 19.9$ cells with folded tails), post-thawed semen showed a significant decrease. Therefore, the results indicated a higher susceptibility of boar spermatozoa to osmotic changes during the freezing and thawing processes.

Table 3. Membrane functionality (\%) of boar semen after thawing and resuspension in BTS and SDM diluents.

\begin{tabular}{ccc}
\hline & BTS & SDM \\
\hline$\%$ Folded tail & $29.20 \pm 0.80 \mathrm{a}$ & $28.20 \pm 8.04 \mathrm{a}$ \\
\hline
\end{tabular}

(a, b) Distinct letters on the same column denotes a statistical significant difference $(\mathrm{p}<0.05)$.

During cryopreservation, the plasmatic membrane suffers modifications, such as phospholipid translocations, owing to temperature change. This 
movement occurs because the membrane undergoes a gel-crystalline transition, which favors the dislocation of proteins to more fluid regions of the membrane, thus allowing the lipids to invert their positions. Along with a higher fluidity, the instability of the membrane also increases, which lead to the loss of permeability. As a result, the membrane becomes vulnerable to ion loss (THOMAS et al., 2006). Such transformations on the sperm membrane during the freezing/thawing procedures can lead to the extrusion and detachment of the acrosomal vesicle, as noted by Silva et al. (2009). These authors analyzed the ultrastructure of in natura, frozen, and post-thawed spermatozoa. Furthermore, such alterations are similar to those of sperm capacitation, and our study also showed a lower percentage of similar damages (Table 4). Therefore, the results suggest that more eficiente sperm cell protection and a higher possibility of fertilization are associated with a greater number of undamaged acrosomes.

Table 4. Acrosomal integrity and sperm vitality of boar semen after thawing and resuspension in BTS and SDM diluents.

\begin{tabular}{lcc}
\hline Analysis & BTS & SDM \\
\hline Undamaged acrosome & $87.4 \pm 11.9 \mathrm{a}$ & $81.7 \pm 17.7 \mathrm{a}$ \\
Living spermatozoa & $50.3 \pm 20.9 \mathrm{~b}$ & $72.3 \pm 16.4 \mathrm{a}$ \\
Living spermatozoa/Undamaged acrosome & $40.1 \pm 17.9 \mathrm{~b}$ & $52.1 \pm 20.5 \mathrm{a}$ \\
\hline
\end{tabular}

$(\mathrm{a}, \mathrm{b})$ Distinct letters on the same column denote a statistically significant difference $(\mathrm{p}<0.05)$.

The freezing/thawing processes cause damage to the sperm cell, decreasing the number of living spermatozoa when the thawing process is completed (SILVA; GUERRA, 2011). In our study, the decrease in sperm vitality was below $50 \%$ for both diluents. However, our SDM alternative showed a higher percentage of living cells than the commercial BTS $(\mathrm{p}<0.05)$ (Table 4).

When analyzing both features (acrosomal integrity and sperm vitality) together, SDM was more effective than BTS $(52.1 \pm 20.5$ and $40.1 \pm$ 17.9, respectively) (Table 4). The positive effects of SDM on the above-mentioned features were possibly caused by proteins such as casein,which make the milk a non-penetrating cryoprotector (BERGERON et al., 2007). Such proteins seem to be linked to binding sperm proteins (BSP). As a result, these proteins cannot bind to the plasmatic membrane, avoiding the cholesterol efflux and maintaining stabilization (MANJUNATH et al., 2002; MANJUNATH, 2012).

\section{Conclusion}

Although skimmed dried milk is four-fold cheaper, more accessible, and easier to manipulate than commercial BTS in some Brazilian regions, our results suggest that BTS was a more efficient diluent of boar semen at the cooling step of the freezing protocol. Further studies verifying whether higher concentrations of skimmed dried milk lead to more efficient sperm preservation in freezing protocols are welcome.

\section{Acknowledgements}

We thank the Conselho Nacional de Desenvolvimento Científico e Tecnologico (CNPq) for funding this study. We are also grateful to the Fundação Cearense de Amparo à Pesquisa (FUNCAP) for providing a grant used to conduct this study. 


\section{Ethics committee}

In our study, all procedures were formally approved by the ethics committee for animal use (registration number 11518234-9/72, CEUA UECE).

\section{References}

ARAÚJO, L. R. S.; DIAS, A. V.; BARROS, T. B.; GUIMARÃES, D. B.; CANTANHÊDE, L. F.; TONIOLLI, R. Adição de betaína ao diluente leite em pó desnatado durante a conservação do sêmen do varrão a $10^{\circ}$ C. Revista Brasileira de Ciências Veterinárias, Fortaleza, Ceará, v. 20, n. 4, p. 234-240, 2013.

BARRETO, M. A. P.; SILVA, J. F. S.; FAGUNDES, B.; CAIADO, J. R. C.; SOUZA, G. V. de; SHIMOYA, A. Efeito de proteínas do plasma seminal eqüino com massa superior a $10 \mathrm{kDa}$ concentradas 10 vezes sobre a congelabilidade do sêmen. Revista Brasileira de Zootecnia, Viçosa, MG, v. 37, n. 12, p. 2115-2119, 2008.

BERGERON, A.; BRINDLE, Y.; BLONDIN, P.; MANJUNATH, P. Milk caseins decrease the biding of the major bovine seminal plasma proteins to sperm and prevent lipid loss from the sperm membrane during sperm storage. Biology of Reproduction, Montreal, v. 77, n. 1, p. 120-126, 2007.

BIANCHI, I.; MADEIRA, E. M.; SCHNELDER, A.; RABASSA, V. R.; CORREAA, E. K.; LUCIA JÚNIOR, T.; CORRÊA, M. N. Efeito de diferentes métodos de congelamento, diluentes e tempos de resfriamento sobre a qualidade do semen suíno criopreservado. Acta Scientiae Veterinariae, Pelotas, v. 39, n. 1, 949-955, 2011.

BORTOLOZZO, F. P.; WENTZ, I.; BENNEMANN, P. E.; BERNADI, M. L.; WOLLMANN, E. B.; FERREIRA, F. M.; BORCHART NETO, G. Suinocultura em ação: inseminação artificial na suinocultura tecnificada. Porto Alegre, Brasil: Copyright, 2005. 185 p.

CORRÊA, M. N.; MEINCKE, W.; LUCIA, J. R. T.; DESCHAMPS, J. C. Inseminação artificial em suínos. Pelotas: Copyright, 2001. 194 p.

CUNHA, I. C. N. Criopreservação do sêmen de cães. 2002. Tese (Doutorado em Reprodução Animal) Universidade Estadual Paulista, Botucatu.

GARCIA, M. A.; GRAHAM, E. F. Dialysis of bovine semen and its effects on fresh and freeze - thawed spermatozoa. Cryobiology, Department of Animal Science, University of Minnesota, v. 24, n. 5, p. 446-454, 1987.
INAMASSU, A.; UECHI, E.; LOPES, M. D. Viabilização do teste hipo-osmótico em cães e sua relação com outras variáveis espermáticas. Revista Brasileira de Reprodução Animal, São Paulo, v. 23, n. 1, p 302-304, 1999.

KULAKSIZ, R.; ÇEBI, Ç.; AKÇAY, E. The effect of different extenders on the motility and morphology of ram sperm frozen or stored at $4^{\circ} \mathrm{C}$. Turk. Journal of Veterinary and Animal Sciences, Kars, v. 36, n. 2, p. 177$182,2012$.

MANJUNATH, P. New insights into the understanding of the mechanism of sperm protection by extender componentes. Animal Reproduction Science, Montreal, v. 9, n. 4, p. 809-815, 2012.

MANJUNATH, P.; NAUC, V.; BERGERON, A.; MENARD, M. Major proteins of bovine seminal plasma bind to the low-density lipoprotein fraction of hen's egg yolk. Biology of Reproduction, Montreal, v. 67, n. 4, p. 1250-1258, 2002.

MEMON, M. A.; OTT, R. S. Methods of semen preservation and artificial insemination in sheep and goats. World Review of Animal Production, Philadelphia, v. 17, n. 1, p. 19-25, 1981.

MICHAJOLOV, N. N. Milk as a semen diluent. Journal of the American Veterinary Medical Association, Hannover, v. 117, n. 1, p. 337-348, 1950.

NIE, G. J.; WENZEL, J. G. W. Adaptation of the hypoosmotic swelling test to acess functional integrity of stallion spermatozoal plasma membranes. Theriogenolog, Philadelphia, v. 55, n. 4, p. 1005-1018, 2001.

SCHMITT, F. L.; MATTOS, R. C.; JOBIM, M. I. M.; OBERST, E. R. A concentração, a composição e a qualidade do plasma seminal na preservação do sêmen eqüino a $+4^{\circ} \mathrm{C}$. Acta Scientiae Veterinarie, Porto Alegre, v. 31, n. 2, p. 135-136, 2003.

SILVA, A. R. Atualidades sobre a criopreservação do sêmen de cães. Revista Brasileira de Reprodução Animal, Mossoró, v. 31, n. 1, p. 119-127, 2007.

SILVA, A. R.; FONTENELE-NETO, J. D.; CARDOSO, R. C. S.; SILVA, L. D. M.; CHINIRÉA, V. H.; LOPES, M. D. Description of ultrastructural damages in frozentwahed canine spermatozoa. Ciência Animal Brasileira, Goiânia, v. 10, n. 2, p. 595-601, 2009.

SILVA, S. V.; GUERRA, M. M. P. Efeitos da criopreservação sobre as células espermáticas e alternativas para a redução das crioinjúrias. Revista Brasileira de Reprodução Animal, Recife, v. 35, n. 4, p. 370-384, 2011.

THOMAS, A. D.; MEYERS, S. A.; BALL, B. A. Capacitation-like changes in equine spermatozoa 
following cryopreservation. Theriogenology, TONIOLLI, R.; JATAHY, P. C.; SILVA, M. C.; Philadelphia, v. 65, n. 8, p. 1531-1550, 2006.

TONIOLLI, R. Pouvoir fecondant des spermatozoïdes de verrat: amèlioration des conditions de conservation. MOREIRA, F. R. C. Utilização do leite desnatado e do ácido 3-indol acético na conservação do semen suíno. Ciência Animal, Mossoró, v. 11, n. 1, p. 21-26, 2001.

1996. Thesis (Doctorate in Life Sciences) - Tours, France. 